\title{
Nucleolar Organizer Regions in Patients with Precancerous and Cancerous Lesions of the Uterine Cervix
}

\author{
V. V. V. S. Murty, A. B. Mitra, J. K. Sharma, \\ and U. K. Luthra
}

\begin{abstract}
Nucleolar organizer regions (Ag-NORs) were studied in patients with cervical precancerous and cancerous lesions along with controls. The data revealed a statistically significant decrease of Ag-NORs in cancer patients, as well as in women with severe precancerous lesions as compared with controls. A similar decrease in the amount of Ag-staining was also observed in both cancer and severe dysplasia cases. The study suggests a possible relationship of Ag-NOR activity to malignancy.
\end{abstract}

\section{INTRODUCTION}

Nucleolar organizer regions (NOR) in humans are visualized as secondary constriction regions of acrocentric chromosomes of $D$ and $G$ groups by silver staining methods $[1,2]$. Hybridization techniques in situ demonstrated that NORs contain the RNA genes for $18 \mathrm{~s}$ and $28 \mathrm{~s}[3,4]$, and somatic cell hybridization techniques further demonstrated that the active NORs are preferentially stained by the silver staining method [5, 6]. The frequency of Ag-NOR was found to be fairly constant in a particular tissue of an individual, although variations also have been reported in different tissues [7-10]. Reports on NOR activity in malignant diseases are contradictory. Some malignant diseases, such as lymphoma, leukemia, and solid tumors, showed fewer or similar number of Ag-NORs to those of healthy individuals [11-13]. On the other hand, an increased frequency of Ag-NORs was reported in the leukocytes of female patients with adenocarcinoma [14] and in hypodiploid tumor cells of meningiomas [15]. In the present communication we report the frequency of AgNORs in the leukocytes of female patients with cervical precancerous and cancerous lesions.

\section{MATERIALS AND METHODS}

Fifty-three women with cervical precancerous lesions (dysplasias), 16 cervical cancer patients, and 37 healthy women were included in the study. The ages of the three groups were more or less matched. The ages for the controls, precancerous,

Cytology Research Centre (ICMR), Maulana Azad Medical College Campus, New Delhi, India.

Address requests for reprints to Dr. A. B. Mitra, Cytology Research Centre, Maulana Azad Medical College Campus, Bahadur Shah Zaffar Marg, New Delhi-110002, India.

Received August 15, 1984; accepted December 17, 1984. 
and cancerous groups were $23-65,22-62$, and $22-60$ years, respectively. Patients were diagnosed cytomorphologically according to WHO criteria [16].

Of the 53 cases of precancerous lesions, 23,22 , and 8 were from mild, moderate, and severe dysplasias, respectively. Cancer patients and some of the patients having precancerous lesions were diagnosed both cytologically and histopathologically. Whole blood was cultured in TC 199 medium supplemented with $20 \%$ heat inactivated human $\mathrm{AB}$ serum and phytohemagglutinin-P for 72 hours. Colcemid $(0.02 \mu \mathrm{g})$ $\mathrm{ml}$ ) was added 2 hours prior to harvesting. Air-dried chromosome preparations were made by a conventional method. Ag-NOR staining was performed according to Howell and Black's method [17]. The amount of Ag-stain on each acrocentric chromosome was recorded visually as 0 (absent), 1 (small), 2 (medium), or 3 (large), according to Miller et al. [18]. Ten metaphases from each subject were scored for positive silver staining of NORs.

\section{RESULTS}

Individual variations in modal numbers of Ag-NORs were observed in the precancerous and cancerous group, as well as in controls (Table 1). The modal numbers varied from 5 to 10 (controls) and 4 to 10 (precancerous lesions) whereas, in cancer patients, the modal number was between 5 and 8.5. The variation of Ag-NORs in cancer cases was lower, and compared with that of normal and precancerous lesion subjects. The average modal number of Ag-NORs was found to be less in cancer cases (6.38), compared with that of controls (7.00). The average Ag-NOR per metaphase was found to be less $(6.25 \pm 0.88)$ in the cancer group compared with controls $(7.03 \pm 0.88)$. The difference was found to be statistically significant ( $p<$ 0.02). The modal number of Ag-NORs in cases with precancerous lesions was 7.0, 7.3, and 6.1 in mild, moderate, and severe dysplasias, respectively. Although there was an apparent decrease in the frequency of Ag-NORs in severe dysplastic cases $(6.23 \pm 1.09)$, the difference was not significant $(p>0.05)$, compared with those of cases with mild $(7.13 \pm 1.21)$ and moderate $(7.23 \pm 1.18)$ dysplasias. Ag-NORs in the precancerous group, as a whole, did not differ from that of controls.

The distribution of Ag-NORs was further analyzed to look into variations with respect to $D$ and $G$ group chromosomes. Analysis revealed that the decreased frequency of Ag-NORs in cancer cases was not due to any specific group of chromosomes (D and G), but was evident in both groups (Table 1). The distribution of the modal number of Ag-NORs among the groups is shown in Table 2. The majority of cases of severe dysplasia $(87.50 \%)$ and cancer $(93.75 \%)$ revealed modal numbers 7 or less, compared with normal women $(56.75 \%)$ and other lower grades of dyspla-

Table 1 Frequency of Ag-NORs in different groups of women

\begin{tabular}{lccccc}
\hline & & \multicolumn{4}{c}{ Silver stained NORs } \\
\cline { 3 - 6 } \multicolumn{1}{c}{ Group } & studied & Modal number & Mean \pm SD/metaphase & D group & G group \\
\hline Controls & 37 & $7.0(5-10)$ & $7.03 \pm 0.88$ & $4.16 \pm 0.76$ & $2.87 \pm 0.70$ \\
Dysplasias & & & & & \\
$\quad$ Mild & 23 & $7.0(4-10)$ & $7.13 \pm 1.21$ & $4.39 \pm 0.74$ & $2.65 \pm 0.78$ \\
$\quad$ Moderate & 22 & $7.3(5-10)$ & $7.23 \pm 1.18$ & $4.38 \pm 0.91$ & $2.85 \pm 0.86$ \\
$\quad$ Severe & 8 & $6.1(4-8)$ & $6.23 \pm 1.10$ & $3.90 \pm 1.09$ & $2.33 \pm 0.49^{b}$ \\
Cancer & 16 & $6.3(5-8.5)$ & $6.25 \pm 0.88^{\mathrm{a}}$ & $3.77 \pm 0.78$ & $2.48 \pm 0.63$ \\
\hline
\end{tabular}

a Significant in $t$ test: $p<0.02$.

bignificant in $\mathbf{t}$ test: $\boldsymbol{p}>\mathbf{0 . 0 5}$. 
Table 2 Distribution of Ag-NORs in different groups of women

\begin{tabular}{|c|c|c|c|c|c|c|}
\hline \multirow[b]{2}{*}{ Group } & \multirow{2}{*}{$\begin{array}{l}\text { Number } \\
\text { studied }\end{array}$} & \multicolumn{5}{|c|}{ Modal number of Ag-NORs } \\
\hline & & 6 & 7 & 8 & 9 & 10 \\
\hline $\begin{array}{l}\text { Controls } \\
\text { Dysplasia }\end{array}$ & 37 & $9(24.32)^{a}$ & $12(32.43)$ & $13(35.13)$ & $1(2.70)$ & $2(5.40)$ \\
\hline Míld & 23 & $5(21.74)$ & $8(34.78)$ & $7(30.43)$ & $2\{8.69\}$ & $1(4.35)$ \\
\hline Moderate & 22 & $5(22.73)$ & $7(31.82)$ & $7(31.82)$ & $1(4.55)$ & $2(9.09)$ \\
\hline Severe & 8 & $5(62.50)$ & $2(25.00)$ & $1(12.50)$ & - & - \\
\hline Cancer & 16 & $9(56.25)$ & $6(37.50)$ & - & $1(6.25)$ & - \\
\hline
\end{tabular}

${ }^{0}$ Numbers in parenthesis indicate percentage.

Table 3 Amount of $\mathrm{Ag}$ stain per acrocentric chromosome in different groups of individuals

\begin{tabular}{|c|c|c|c|c|}
\hline \multirow[b]{2}{*}{ Group } & \multirow{2}{*}{$\begin{array}{l}\text { Number of } \\
\text { individuals }\end{array}$} & \multicolumn{2}{|c|}{ Ag stain per chromosome } & \multirow{2}{*}{$\begin{array}{l}\text { Ag stain per } \\
\text { acrocentric } \\
\text { chromosome }(D+G)\end{array}$} \\
\hline & & D group & G group & \\
\hline Controls & 37 & 1.0388 & 1.1308 & 1.0555 \\
\hline \multicolumn{5}{|l|}{ Dysplasia } \\
\hline Mild & 23 & 1.3061 & 1.1578 & 1.2468 \\
\hline Moderate & 22 & 1.0089 & 0.9178 & 0.9725 \\
\hline Severe & 8 & 0.8816 & 0.7895 & 0.8447 \\
\hline Cancer & 16 & 0.8570 & 0.8602 & 0.8583 \\
\hline
\end{tabular}

sias (Table 2). Rarely, an individual with cancer had modal numbers 8 or more $(6.25 \%)$, compared with controls $(40.74 \%)$. Further, none of the groups showed any age relationship with $\mathrm{Ag}-\mathrm{NORs}$ by regression analysis.

The results on the amount of Ag stain per acrocentric chromosome are shown in Table 3. The data revealed an apparent decreasing trend in the amount of $\mathrm{Ag}$ stain from controls to cancer, except in mild dysplasia cases. The decrease in the amount of Ag stain per acrocentric chromosome in cancer and severe dysplasia cases was almost similar. The data from both mean NOR value and amount of Ag stain per chromosome indicated decreased activity of rDNA regions in both cancer and severe dysplasia cases, in comparison with controls and mild-to-moderate dysplasia cases.

\section{DISCUSSION}

Our results indicate a decrease in the frequency of Ag-NORs in cancer cases, in comparison with controls. The data also revealed an apparent decrease of Ag-NORs in severe dysplasia cases when compared with controls. The trend of decrease in the frequency of Ag-NORs in cancer and severe dysplasia cases is interesting, because the progression rate of this severe grade of precancerous lesion to cancer was reported to be significantly more in comparison with milder forms of precancerous groups [20-23].

The clinical significance of Ag-NOR activity is not known; however, there have been several reports on the decrease of Ag-NORs in leukemia and lymphoma [1114]. A significant decrease of Ag-NORs was also reported in a case of CML in blastic crisis [24]. Excluding the report by Cheng et al. [15], no data are available thus far on the increase of $\mathrm{Ag}-\mathrm{NOR}$ frequency in patients with adenocarcinoma. Recently, 
Schulze et al. [14] found no detectable increase in the number of active NORs in cells of patients with malignant disease. However, a remarkably low NOR activity was observed in infectious mononucleosis. Evidence also showed that tumor cells release certain factors that had varied effects on circulating lymphocytes [18].

Some unknown serum factor may be responsible for suppressive action on rDNA transcription. However, the relation of rDNA activity and Ag-NOR is not clear, since inhibition of RNA synthesis by actinomycin D did not give consistent results [25].

Our analysis of the amount of $\mathrm{Ag}$ stain also revealed a decreased value per acrocentric chromosome in cancer $(0.85)$ and severe dysplasia cases $(0.84)$, in comparison with controls (1.05). It is likely that this variation in the amount of $\mathrm{Ag}$ stain is due to difference in the amount of rDNA, because hybridization in situ $[26,27]$ and filter hybridization [28] demonstrated that acrocentric chromosomes differ in the number of copies of rRNA genes they carry. In view of the nature of Ag stained material at the NOR [29], however, it is likely that this may not account for all the variations of $\mathrm{Ag}$ stain we have seen in our material.

In our analysis, the data did not show any age relationship with the frequency of Ag-NORs, as was reported by an earlier study on normal individuals [30]. The reasons for such difference in observation is not clear. Further comment on age relationship of Ag-NOR from this study may not be possible, since we do not have individuals of all age groups, especially patients younger than age 20.

In view of the variable biologic behavior of the dysplastic lesions of the uterine cervix, the observation of reduced activity of Ag-NOR in both cancer and severe dysplasia cases seems to be significant. Various prospective studies have demonstrated higher progression rates for severe dysplasia cases, compared with other milder groups of dysplasia. The decrease of Ag-NOR in severe dysplasia indicates the possibility that this phenomenon may have some implication in relation to the development of malignancy. The exact relation of the activity of ribosomal genes with malignancy is not known. The question regarding the expression of Ag-NORs and the development of malignancy appears to be of interest.

The authors are thankful to gynecologists of Lok Nayak Jaiprakash Narain, Kasturba, Swami Dayanand, and Ram Manohar Lohia Hospitals for providing access to the clinical material. Thanks are also due to N. S. Murthy for statistical advice and Mahendra Pratap for excellent preparation of the material.

\section{REFERENCES}

1. Howell WM, Denton TE, Diamond JR (1975): Differential staining of the satellite regions of human acrocentric chromosomes. Experientia 31:260-262.

2. Goodpasture C, Bloom SE (1975): Visualization of nucleolar organizer regions in mammalian chromosomes using silver staining. Chromosoma 53:37-50.

3. Henderson AS, Warburton D, Atwood KC (1972): Localization of ribosomal DNA in the human chromosome complement. Proc Natl Acad Sci USA 69:3394-3398.

4. Evans HJ, Buckland RA, Pardue ML (1974): Location of genes coding for 18 s and $28 \mathrm{~s}$ ribosomal RNA in the human genome. Chromosoma 48:405-426.

5. Miller DA, Dev VG, Tantravathi R, Miller OJ (1976): Suppression of human nucleolus organizer activity in mouse-human somatic hybrid cells. Exp Cell Res 101:235-243.

6. Miller OJ, Miller DA, Dev VG, Tantravahi R, Croce CM (1976): Expression of human and supression of mouse nucleolus activity in mouse-human somatic cell hybrids. Proc Natl Acad Sci USA 73:4531-4535.

7. Mikelsaar AV, Schwarzacher HG (1978): Comparison of silver staining of nucleolus organizer regions in human lymphocytes and fibroblasts. Hum Genet 42:291-299. 
8. Reeves BR, Casey G, Harris H (1982): Variations in the activity of nucleolar organizers in different tissues, demonstrated by silver staining of human normal and leukemic cells. Cancer Genet Cytogenet 6:223-230.

9. Schwarzacher HG, Watchtler F (1983): Nucleolus organizer regions and nucleoli. Hum Genet 63:89-99.

10. Varley IM (1977): Patterns of silver staining of human chromosomes. Chromosoma 61:207-214.

11. Hubbell HR, Hsu TC (1977): Identification of nucleolus organizer regions (NORs) in normal and neoplastic human cells by the silver staining technique. Cytogenet Cell Genet 19:185-196.

12. Trent JM, Carlin DA, Davis JR (1981): Expression of silver-stained nuclelar organizing regions (Ag-NORs) in human cancer. Cytogenet Cell Genet 30:31-38.

13. Schulze B, Golinski C, Fonatsch C (1984): Heterochromatin and nucleolus organizer regions in cells of patients with malignant and premalignant lymphatic diseases. Human Genet 67:391-395.

14. Cheng DM, Denton TE, Liem SL, Elliot Cl (1981): Variation in nucleolar organizer activity in lymphocytes of female with adenocarcinoma. Clin Genet 19:145-148.

15. Zankl H, Huwer $\mathrm{H}$, Zang KD (1982): Cytogenetic studies on the nucleolar organizer regions (NORs) activity in meningioma cells with normal and hypodiploid karyotypes. Cancer Genet Cytogenet 6:47-53.

16. World Health Organization (1973): Cytology of the Female Genital Tract. WHO Monograph Series 3.

17. Howell WH, Black DA (1980): Controlled silver staining of nucleolus organizer regions with a protective colloidal developer. A 1 step method. Experentia 36:1014-1015.

18. Werkmesiter J, Zaunders J, Mc Carthy W, Hersey P (1980): Characterization of an inhibitor of cell division released in tumour cell cultures. Clin Exp Immunol 41:487-496.

19. Miller DA, Tantravahi R, Dev VG, Miller OJ (1977): Frequency of satellite association of human chromosomes is correlated with amount of Ag-staining of the nucleolus organizer region. Am J Hum Genet 29:490-502.

20. Luthra UK, Saraswati M, Wahi PN (1969): Cervical dysplasia: Its signicicance. III. Biological behaviour. Indian J Med Res 57:629-641.

21. Gellman DD (1976): Cervical cancer screening programmes. 1. Epidemiology and natural history of carcinoma of cervix. Can Med Assoc J 114:1003-1012.

22. Briggs RM (1979): Dysplasia and early neoplasia-A review. Obstet Gynecol Surv 34:70-99.

23. Heinzl S, Szalmay G, Jochum L, Roemer V (1982): Observation on the development of dysplasia. Acta Cytologica 20:453-456.

24. Mamaev NN, Mamaeva SE, Bandapadkhaia D, Medvedeva NV (1980): The activity of nucleolar organizer regions in chromosomes from normal, leukemic and tumor cells of man studies with silver nitrate staining (English Summary). Tsitologiia 22:161-167.

25. Raman R, Sperling K (1981): Patterns of silver staining on NORs of prematurely condensed muntjac chromosome following RNA inhibition. Exp Cell Res 135:373-378.

26. Henderson AS, Warburton D, Atwood KC (1972): Location of ribosomal DNA in the human chromosome complement Proc Natl Sci USA 69:3394-3398.

27. Evans HJ, Buckland RA, Pardue ML (1974): Location of the genes coding for 18s and 28s ribosomal RNA in the human genome. Chromosoma 48:405-426.

28. Dittes H, Krone W, Bross K, Schmid M, Vogel W (1974): Biochemical and cytogenetic studies on the nucleolus organizer regions (NORs) of man. Human Genetik 26:47-59.

29. Schwarzacher HG, Wachtler F (1983): Nucleolus organizer regions and nucleoli. Hum Genet 63:89-99.

30. Denton TE, Leirn SL, Cheng KM, Barrett JV (1981): The relationship between aging and ribosomal gene activity in humans as evidenced by silver staining. Mech Aging Devel 15:1-7. 